\title{
Archaeological Investigation to Locate the Northwest Corner of Mission Concepcion San Antonio, Bexar County, Texas
}

Anne A. Fox

Center for Archaeological Research

Follow this and additional works at: https://scholarworks.sfasu.edu/ita

Part of the American Material Culture Commons, Archaeological Anthropology Commons, Environmental Studies Commons, Other American Studies Commons, Other Arts and Humanities Commons, Other History of Art, Architecture, and Archaeology Commons, and the United States History Commons

Tell us how this article helped you.

This Article is brought to you for free and open access by the Center for Regional Heritage Research at SFA ScholarWorks. It has been accepted for inclusion in Index of Texas Archaeology: Open Access Gray Literature from the Lone Star State by an authorized editor of SFA ScholarWorks. For more information, please contact cdsscholarworks@sfasu.edu. 


\section{Archaeological Investigation to Locate the Northwest Corner of Mission Concepcion San Antonio, Bexar County, Texas}

\section{Creative Commons License}

\section{(c) (1) \&}

This work is licensed under a Creative Commons Attribution-NonCommercial 4.0 International License 


\section{ARCHAEOLOGICAL INVESTIGATION TO LOCATE THE NORTHWEST CORNER OF MISSION CONCEPCIÓN \\ SAN ANTONIO, BEXAR COUNTY, TEXAS}

Center for Archaeological Research

The University of Texas at San Antonio Archaeological Survey Report, No. 212

1992 



\title{
ARCHAEOLOGICAL INVESTIGATION TO LOCATE \\ THE NORTHWEST CORNER OF MISSION CONCEPCIÓN \\ SAN ANTONIO, BEXAR COUNTY, TEXAS
}

\author{
Anne A. Fox
}

Center for Archaeological Research The University of Texas at San Antonio ${ }^{8}$ Archaeological Survey Report, No. 212 



\begin{abstract}
On May 2, 1990, the Center for Archaeological Research (CAR), The University of Texas at San Antonio, conducted an archaeological investigation to locate the north wall of the compound of Mission Concepción for the San Antonio Missions National Historical Park. The purpose of the investigation was to obtain information in order to be able to project the north wall line and the west wall line and locate the original northwest comer which has been eliminated by street and utility construction.
\end{abstract}




\section{TABLE OF CONTENTS}

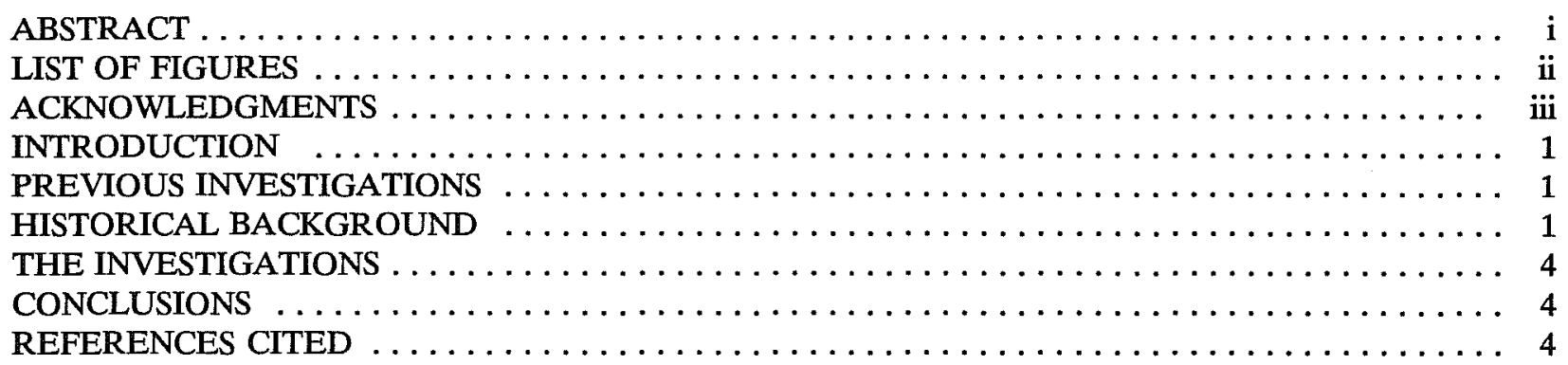

\section{LIST OF FIGURES}

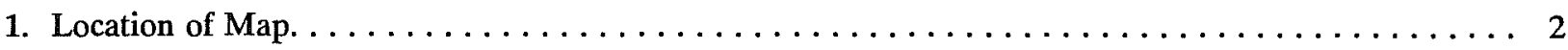

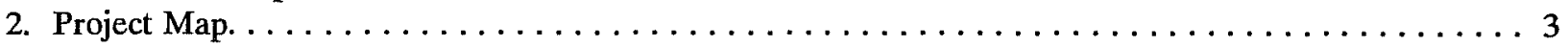




\section{ACKNOWLEDGMENTS}

We would like to acknowledge the contribution of Los Compadres de San Antonio Missions National Historical Park for financing this small project. Also, the cooperation and interest of the members of the park staff are appreciated. I. Waynne Cox of the Center staff mapped and recorded the location of the investigation in relation to the known landmarks on the site. 


\section{INTRODUCTION}

On May 2, 1990, the author directed the excavation of a short backhoe trench across the expected location of the north wall of the mission compound at Mission Concepción (Figure 1). The work was done under contract between the UTSA Center for Archaeological Research (CAR) and the National Park Service. Mission Concepción is a part of the San Antonio Missions National Historical Park. It is also a State Archaeological Landmark, is listed on the National Register of Historic Places, and has been recorded by the Historic American Buildings Survey. The investigation was done in compliance with Section 106 of the National Historic Preservation Act of 1966 (as amended) and Executive Order 11593.

The work was completed within one day, and involved a backhoe and several CAR staff members. The purpose of the investigation was to establish the location of the north wall in order to project the line of the wall until it met the line of the west wall, as previously established, so as to determine the location of the northwest corner of the compound. During completion of a recent archaeological investigation (Brown n.d.) this corner was found to have been destroyed by utility trenches.

\section{PREVIOUS INVESTIGATIONS}

A number of archaeological investigations have been conducted to locate and map the outer walls of the mission compound, with special emphasis on the north and west walls. In the fall of 1971 and spring of 1972, investigations under the direction of Dan Scurlock of the Texas Historical Commission (Scurlock and Fox 1977) located traces of the west wall in what was then an open field across the road from the mission buildings.

During the fall of 1981 and spring of 1982, the CAR (Ivey and Fox n.d.) conducted selective excavations to locate a number of structures and walls, including the northeast corner and the line of the north wall, and a portion of the west wall not far from Scurlock's excavations.

In 1985, the City of San Antonio initiated a project to realign Mission Road to run outside the west wall of the mission. After several false starts, the project began in February of 1987 with the investigation by CAR of the area to be impacted by the new roadway (Labadie 1989). It was determined that the road would not impact any Spanish colonial resources, and that it would pass over and without severely damaging the acequia that once ran across the area.

At this point, the first half of the realignment of the road was accomplished and traffic was routed away from the front of the mission. In 1990, the CAR conducted a second phase of work (Brown n.d.). This was to find and map the section of the west wall between the old location of Mission Road and the proposed new location, before the second half of the road was moved. During this investigation, a series of backhoe trenches across the wall line exposed sections of the wall and also disclosed areas disturbed by later construction of houses and utility lines (Figure 2). When it was determined that the northwest corner of the mission had been removed by utility trenches, it was decided to undertake one additional backhoe investigation to confirm the location of the corner. The result is the subject of this report.

\section{HISTORICAL BACKGROUND}

For a comprehensive history of the mission, the reader is referred to Father Marion Habig's 1968 book, The Alamo Chain of Missions, A History of San Antonio's Five Old Missions, as well as to the historical background sections of several publications resulting from archaeological investigations, including Ivey and Fox (n.d.), Fox (1988), and Labadie (1989). 


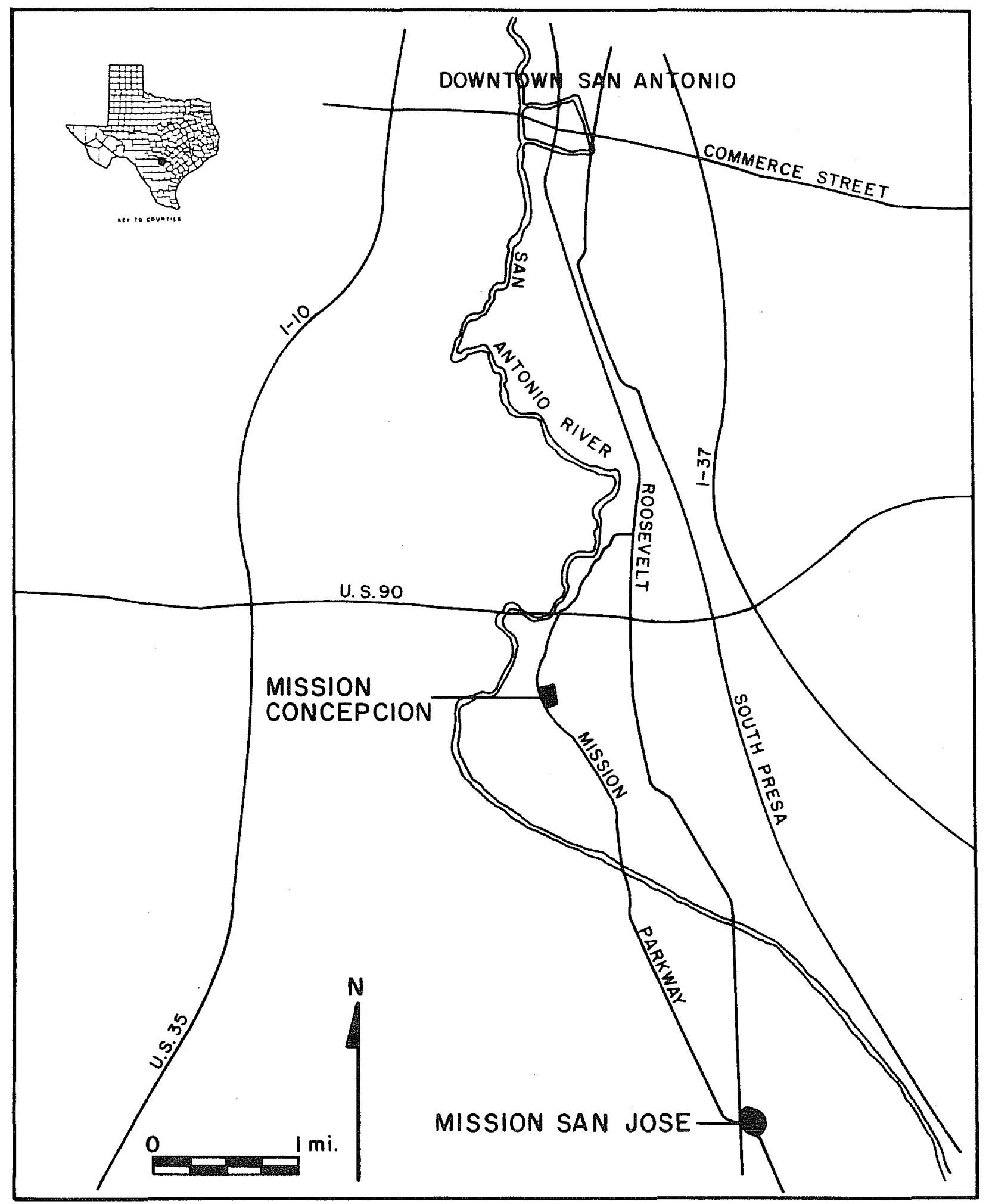

Figure 1. Location Map.

2 


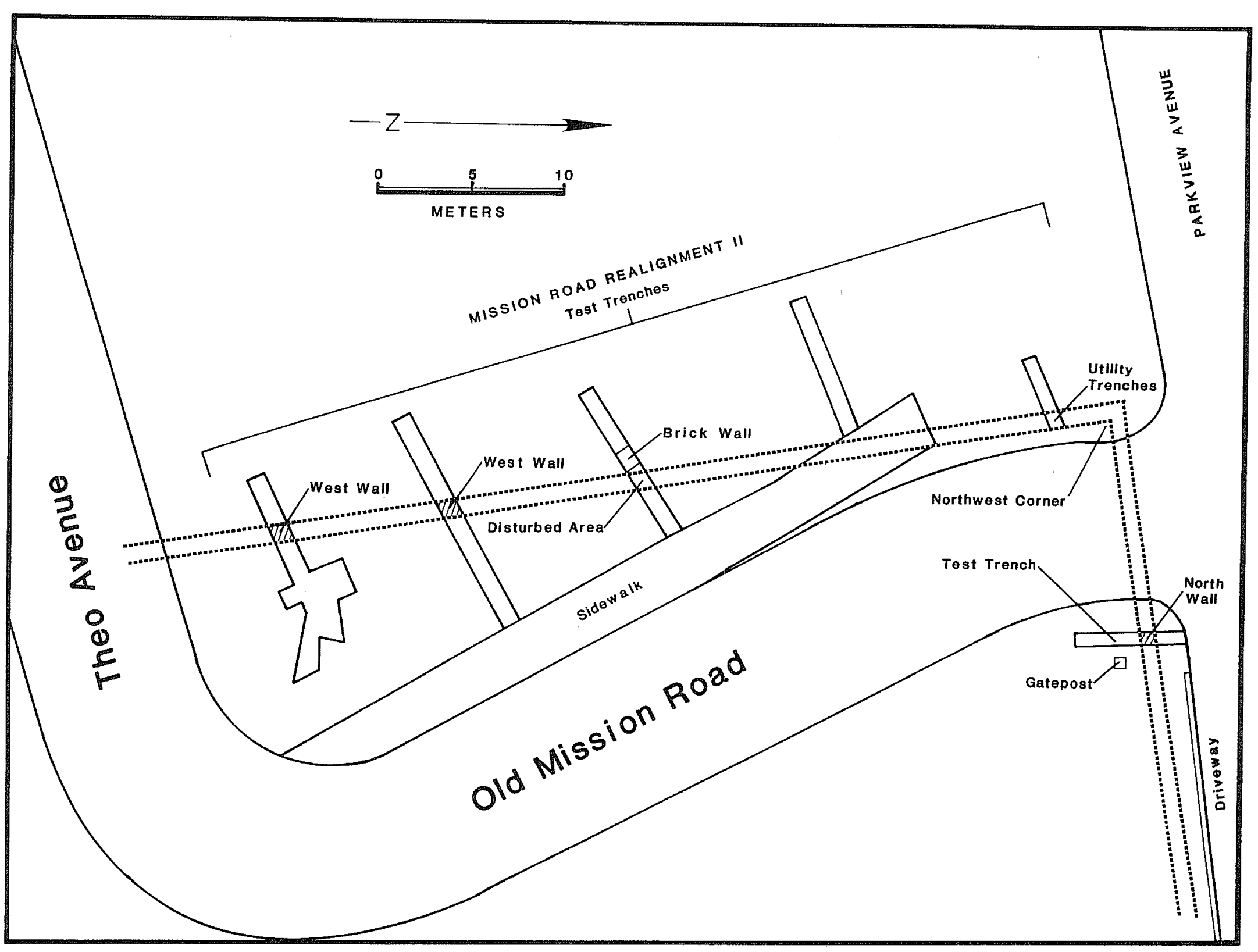

Figure 2. Project Map. Shown are previous and current test trenching that indicate the west and north wall alignments, and the projected northwest corner of the Mission Concepción quadrangle. 


\section{THE INVESTIGATIONS}

A backhoe trench $80 \mathrm{~cm}$ wide and approximately $5 \mathrm{~m}$ long was laid out $60 \mathrm{~cm}$ from the western face of the southernmost brick gatepost on the south side of the entrance drive to the St. John's Seminary buildings (Figure 2). The trench long axis was oriented to magnetic north. Approximately $1.25 \mathrm{~m}$ north of the gatepost, at ca. $75 \mathrm{~cm}$ below the surface, the top of the north wall of the compound was found. The wall was found to measure approximately $75 \mathrm{~cm}$ in thickness. The depth to the bottom of the wall was not determined, but it continued more than $1 \mathrm{~m}$ below the surface, where the trenching stopped.

\section{CONCLUSIONS}

The location of the northwest corner of the mission compound can be determined by projecting the lines of the west and north walls until they meet (Figure 2). This bit of information can now be added to the accumulated data about the outlines of the mission recovered by previous archaeological investigations. It can also be used in the future to relocate the northwest corner on the ground when the time comes to suitably indicate the mission walls on or above the ground surface.

\section{REFERENCES CITED}

Brown, $\mathbf{M}$.

n.d. Archaeological and Historical Investigations for the Mission Road Realignment Project, San Antonio, Texas, Phase II. Center for Archaeological Research, The University of Texas at San Antonio, manuscript in preparation.

Fox, A. A.

1988 Archaeological Investigations at Mission Concepción, Fall of 1986. Center for Archaeological Research, The University of Texas at San Antonio, Archaeological Survey Report 172.

Habig, Fr. M. A.

1986 The Alamo Chain of Missions, A History of San Antonio's Five Old Missions. Franciscan Herald Press, Chicago.

Ivey, J.E. and A. A. Fox

n.d. Archaeological Investigations at Mission Concepción and Mission Parkway. Center for Archaeological Research, The University of Texas at San Antonio, Archaeological Survey Report 114. Manuscript on file at Center for Archaeological Research.

Labadie, J. H.

1989 Archaeological and Historical Investigations for the Mission Road Realignment Project, San San Antonio, Texas. Center for Archaeological Research, The University of Texas at San Antonio, Archaeological Survey Report 173. 
Scurlock, D. and D. E. Fox

1977 An Archeological Investigation of Mission Concepción, San Antonio, Texas. Office of the State Archeologist, Report 28. 
